\title{
PENDAMPINGAN PEMASARAN GULA AREN MENGGUNAKAN MEDIA SOSIAL INSTAGRAM DI DESA UJUNG TEBU KABUPATEN SERANG
}

\author{
Dwi Nurina Pitasari ${ }^{1 *}$, Marthalena ${ }^{2}$ Felycia $^{3}$ \\ ${ }^{123}$ Prodi Ilmu Komunikasi Fisipkum Universitas Serang Raya \\ Corresponding Author: ${ }^{*}$ dwi.nurina@gmail.com
}

\begin{abstract}
Ujung Tebu village has abundant natural resource potential, especially the main ingredient for making palm sugar. The problem faced by the community as partners is the decline in palm sugar sales due to low public knowledge in marketing techniques using social media so that palm sugar products are only marketed in the surrounding environment. The purpose of this activity is to provide assistance to the community, especially palm sugar entrepreneurs regarding interesting marketing techniques using social media, especially Instagram. The method used goes through several stages, namely the first delivery of material to the community as participants, then the second stage is the assistance in creating Instagram accounts and marketing techniques. The result of this activity is the desire of the palm sugar entrepreneur community to market palm sugar using Instagram social media so that it is easier to sell and can increase their income and marketing outside the region.
\end{abstract}

Keywords : Palm sugar marketing, Instagram social media, Ujung Tebu Village

\begin{abstract}
Abstrak
Desa Ujung Tebu ini memiliki potensi sumber daya alam yang sangat melimpah terutama bahan utama membuat gula aren. Permasalahan yang dihadapai oleh masyarakat sebagai mitra adalah penurunan penjualan gula aren karena rendahnya pengetahuan masyarakat dalam teknik pemasaran menggunakan media sosial sehingga produk gula aren hanya dipasarkan di lingkungan sekitar. Tujuan kegiatan ini adalah melakukan pendampingan kepada masyarakat terutama pengusaha gula aren mengenai teknik pemarasan yang menarik dengan menggunakan media sosial terutama Instagram. Metode yang digunakan melalui beberapa tahap yaitu pertama penyampaian materi kepada warga masyarakat sebagai peserta, kemudian dilanjutkan tahap kedua pendampingan pembuatan akun Instagram dan teknik pemasarannya. Hasil dari kegiatan ini muncul keinginan masyarakat pengusaha gula aren untuk memasarkan gula aren menggunakan media sosial Instagram agar lebih mudah dijual serta dapat meingkatkan pendapatan dan pemasaran mereka hingga ke luar daerah.
\end{abstract}

Kata Kunci: Pemasaran Gula Aren, Media Sosial Instagram, Desa Ujung Tebu

Dwi Nurina Pitasari,dkk., Pendampingan Pemasaran Gula Aren Menggunakan Media Sosial Instagram di Desa Ujung Tebu Kabupaten Serang 


\section{PENDAHULUAN}

Desa Ujung Tebu memiliki potensi sumber daya alam yang sangat melimpah terutama bahan utama dalam membuat gula aren. Gula aren adalah gula yang dihasilkan secara alami dan di dapatkan dari pohon enau atau pohon aren (Arenga pinnata). Gula aren terbuat dari air nira yang berasal dari tandan bunga jantan pohon enau, biasanya masyarakat sekitar menyebut pohon tersebut dengan sebutan pohon kaung.

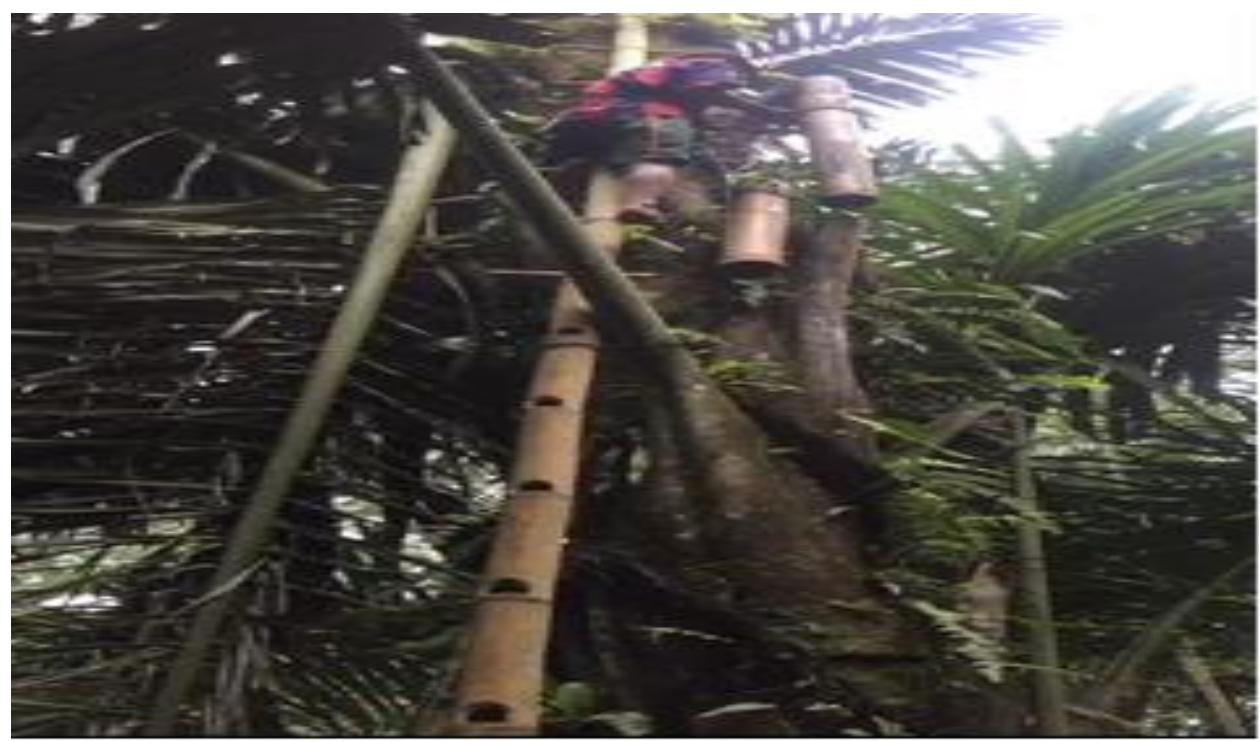

Gambar. 1

Proses Pengambilan Air Nira

Sumber: Data peneliti 2020

Berdasarkan data yang di dapat saat observasi oleh tim di ketahui bahwa masyarakat pengusaha gula aren membuat gula aren tidak setiap hari namun ketika ada yang memesan saja dan hanya memasarkan produknya di wilayah sekitar. Hal ini terjadi karena daerah tersebuh masih sulit di jangkau oleh transportasi umum dan adanya kendala dalam pemasaran gula aren apalagi di saat pandemi Covid-19. Walaupun demikian, masyarakat daerah tersebut sudah memiliki fasilitas komunikasi seperti telepon seluler. Ini membuktikan bahwa teknologi informasi telah masuk dan dapat dirasakan di daerah terpencil

Dwi Nurina Pitasari,dkk., Pendampingan Pemasaran Gula Aren Menggunakan Media Sosial 
walaupun dengan keterbatasan

jaringan.

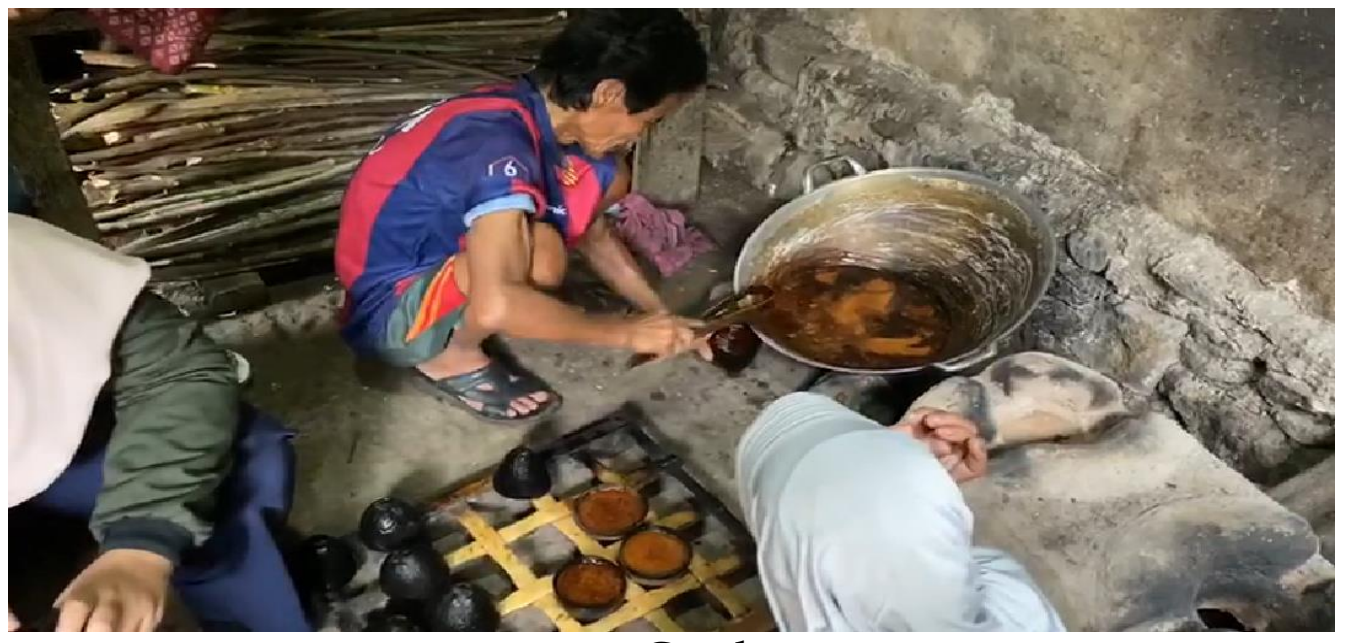

Gambar. 2

Proses Pembuatan Gula Aren

Sumber: Data peneliti 2020

Saat ini kita memasuki Era Revolusi 4.0 yang menuntut kita untuk siap hidup berdampingan dengan berbagai kecanggihan teknologinya dalam pemenuhan informasi dan pengetahuan. Perkembangan teknologi dan informasi yang begitu pesat sehingga munculah internet. Internet membuat segalanya lebih mudah. Internet dengan memanfaatkan website, blog, dan media sosial dapat menjadi solusi untuk mempromosikan produk dan potensi lokal Indonesia ke mancanegara. Media sosial telah menjadi pilar utama dalam penyampaian informasi. Media sosial dapat dipergunakan untuk sosialisasi program dan kebijakan, memperkenalkan produk dan potensi Indonesia, memulihkan dan meningkatkan citra pariwisata serta media sosial dapat dipergunakan sebagai sarana pembelajaran masyarakat (Suryani, 2015).

Asosiasi Pemasaran Amerika (Kotler dan Amstrong, 2012) menyatakan bahwa pemasaran merupakan proses sosial dan manajerial yang di dalamnya individu dan kelompok mendapatkan hal-hal

Dwi Nurina Pitasari,dkk., Pendampingan Pemasaran Gula Aren Menggunakan Media Sosial 
yang mereka butuhkan dan inginkan dengan menciptakan, menawarkan dan secara bebas mempertukarkan produk yang bernilai dengan pihak lain. Bila dikaitkan dengan pengertian tersebut dapat dilihat bahwa masyarakat Desa Ujung Tebu sebagai individu atau kelompok pengusaha gula aren ingin menawarkan gula aren kepada pihak lain.

Seperti yang telah disebutkan diatas bahwa media sosial dapat menjadi solusi untuk mempromosikan produk dan potensi lokal maka pemasaran gula aren di Desa Ujung Tebu berinovasi dengan menggunakan media sosial. Media sosial adalah medium di internet yang memungkinkan penggunanya berinteraksi, bekerjasama, berbagi dan berkomunikasi dengan pengguna lainnya dan membentuk ikatan secara virtual. Media sosial ini digunakan sebagai salah satu alternatif pemasaran gula aren di tengah situasi dan kondisi pandemi Covid-19 yang berkepanjangan. Media sosial yang paling banyak digunakan adalah Facebook, Twitter

dan Instagram.(Elvina, 2019). Media sosial yang digunakan disini adalah Instagram karena dianggap sedang disukai oleh masyarakat saat ini. Oleh karena itu, dalam kegiatan pengabdian pada masyarakat ini dilakukan pendampingan pemasaran gula aren menggunakan media sosial Instagram di Desa Ujung Tebu Kabupaten Serang dengan harapan dapat memperluas jangkauan pemasaran dan meningkatkan penjualan sehingga mendapatkan keuntungan.

\section{METODE PELAKSANAAN}

Teknik pengumpulan data dalam kegiatan pengabdian ini dengan melakukan observasi, wawancara dan dokumentasi. Sumber data yang digunakan adalah data primer dan sata sekumder. Data primer yaitu melakukan observasi langsung ke Desa Ujung Tebu dan diperdalam melalui wawancara dengan masyarakat pengusaha gula aren mengenai

Dwi Nurina Pitasari,dkk., Pendampingan Pemasaran Gula Aren Menggunakan Media Sosial 
pemasaran. Sedangkan data sekunder yaitu data yang diperoleh dari pengumpulan data yang menunjang data primer seperti buku, penelitian, kepustakaan, dan referensi lain yang menunjang studi dokumen.

Metode yang digunakan dalam kegiatan pegabdian masyarakat ini adalah berupa kegiatan workshop dan pendampingan terkait pemasaran gula aren melalui Instagram. Kegiatan ini menggunakan media komunikasi yang efektif dengan cara melakukan kegiatan workshop mengenai penggunaan dan pemanfaatan sosial media Instagram dalam pemasaran gula aren untuk meningkatan penjualan dan pendapatan masyarakat pengusaha gula aren di Desa Ujung Tebu, Kecamatan Ciomas, Kabupaten Serang, kemudian dilanjutkan dengan kegiatan penyuluhan tentang kewirausahaan dan pendampingan pembuatan Intagram. Dengan metode ini informasi yang diberikan bukan hanya teori namun dibarengi dengan praktek langsung memasarkan gula aren di sosial media Instagram sehingga di rasa cukup efektif dan efisien.

\section{HASIL DAN PEMBAHASAN}

Dalam kondisi pandemi Covid19 yang berkepanjangan, masyarakat mulai merasakan dampaknya terutama dalam pemenuhan kehidupan seharihari baik sandang maupun papan. Masyarakat dituntut kretaif agar dapat bertahan di tengah situasi ini. Tim pengabdian masyarakat melihat bahwa masyarakat Desa Ujung Tebu perlu tambahan wawasan dan pengetahuan terkait dengan pemasaran menggunakan media sosial dan kewirausahaan agar dapat meningkatkan penjualan gula aren dalam bentuk workshop dan pendampingan.

Kegiatan workshop dan pendampingan ini dilaksanakan di salah satu rumah atau balai Pondok Pesantren yang ada di lingkungan sekitar yaitu Pondok Pesantren Darul Fikar. Balai di Pondok pesantren ini

Dwi Nurina Pitasari,dkk., Pendampingan Pemasaran Gula Aren Menggunakan Media Sosial 
sedang tidak digunakan karena pemasaran gula aren yang lebih kreatif kegiatan di pondok pesantren ini dengan menggunakan media sosial tengah diliburkan terkait pandemi Instagram. Jumlah peserta yang hadir Covid-19 yang melanda. Peserta yang berjumlah sekitar kurang lebih 20 hadir dalam kegiatan ini sebagian besar orang dan ini sudah mencapai target meupakan ibu-ibu dan remaja. Remaja sasaran karena memang jumlah peserta dianggap lebih familyar dalam yang di batasi terkait pandemi Covidmenggunakan media sosial dan 19. diharapkan mampu membantu

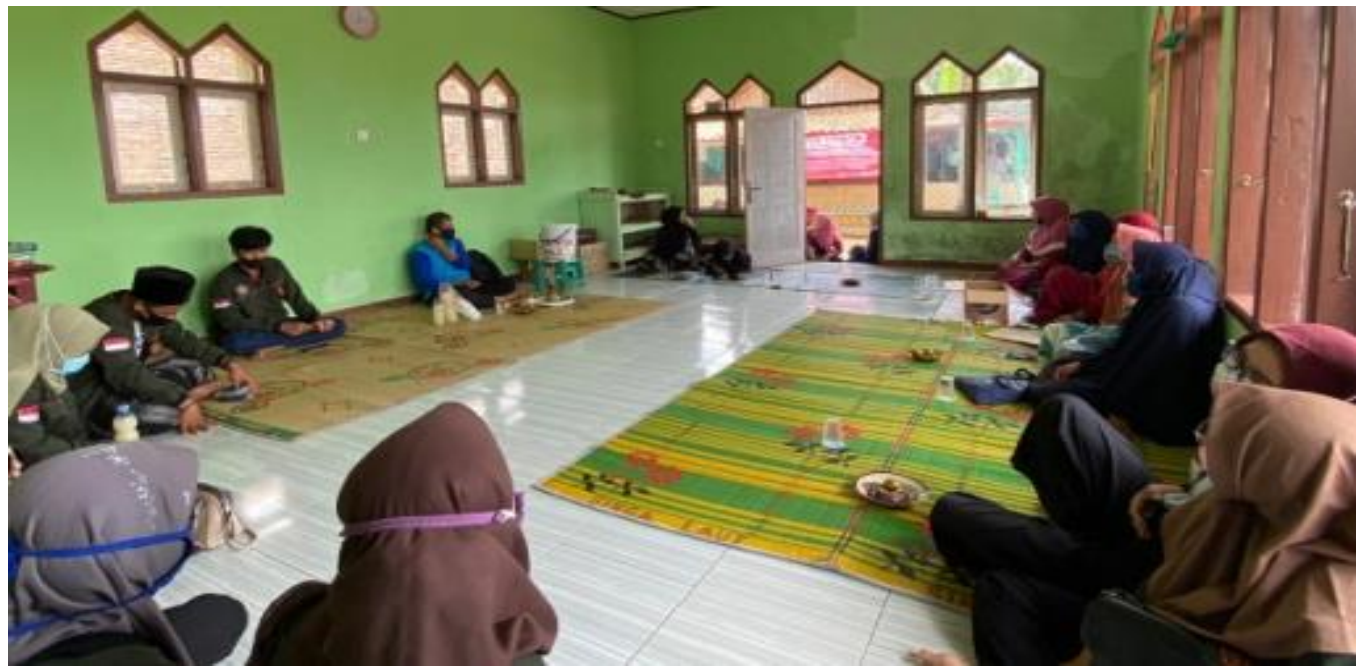

Gambar. 3

Proses Workshop Sumber : Tim Pengabdian 2020

Dalam pelaksaaan workshop dan pendapingan ini kami sangat menjaga protokol kesehatan dengan menerapkan 3M (Mencuci Tangan, Memakai Masker dan Menjaga Jarak. Hal ini dapat terlihat dari foto yang ada, dimana kami menjaga jarak saat acara berlangsung dan selalu mengenakan masker. Pelaksanaan kegiatan pengabdian ini dilaksanakan melalui tiga tahap yaitu tahap awal, tahap inti dan tahap akhir. Secara umum tahapan kegiatan pengabdian ini sebagai berikut:

Dwi Nurina Pitasari,dkk., Pendampingan Pemasaran Gula Aren Menggunakan Media Sosial Instagram di Desa Ujung Tebu Kabupaten Serang 
A. Tahap awal. Kegiatan pada tahap ini meliputi:

(a) observasi dan survey lapangan dilakukan sebagai analisis awal untuk mendapat informasi mendalam dan menyeluruh mengenai permasalahan yang ada dan mencari solusi yang dibutuhkan dan tepat sasaran;

(b) kelengkapan administrasi dilakukan sebagai prosedur formal untuk melegalkan kegiatan pengabdian; dan

(c) merancang kegiatan inti dan menyusun program kerja yang sesuai dengan kebutuhan mitra dan sebagai solusi dari permasalahan yang dihadapi.

Disini tim membuat jadwal kegiatan inti dan pendampingan, membuat modul pelatihan yang akan digunakan, mendata jumlah pengusaha gula aren.

B. Tahap inti. Dalam tahap kedua ini, fokus kegiatan pengabdian yang dilakukan yaitu pendampingan dan bimbingan kepada mitra melalui serangkaian workshop. Adapun kegiatan yang dilaksanakan, yaitu :

1. Kegiatan Knowledge sharing mengenai pemasaran produk khususnya gula aren serta pemanfaatan media sosial khususnya Instagram kepada warga Desa Ujung Tebu yang hadir sebagai pesrta workshop. Tujuan dari kegiatan ini adalah agar warga mengetahui terkait cara, fungsi dan teknik pemasaran gula aren menggunakan media sosial khususnya Instagram. Selain itu, tim melakukan penyuluhan tentang kewirausahaan untuk membekali warga atau pengusha gula aren dalam menjalankan usahanya dan sosialisasi tentang protokol kesehatan dan bahaya COVID-19. Kegiatan ini dilaksanakan dengan memaparkan materi, kemudian dilanjutkan kegiatan workshop.

Kegiatan ini dihadiri oleh peserta dari kalangan ibu-ibu dan remaja. Mereka nampak senang dan antusias sekali yang terlihat dari berbagai pertanyaan yang disampaikan. Harapan mereka kegiatan seperti ini akan terus berlanjut karena mereka sadar bahwa mereka tidak memiliki pengetahuan terkait dengan pentingnya pemasaran menggunakan media sosial untuk

Dwi Nurina Pitasari,dkk., Pendampingan Pemasaran Gula Aren Menggunakan Media Sosial 
meningkatkan penjualan produk gula aren. Selama ini gula aren hanya di pasarkan secara mulut ke mulut ketika ada pesanan dan pada hari pasaran di pasar terdekat di lingkungan ini. Mereka tidak mengetahui apabila produk gula aren jika di kemas dengan kemasan yang lebih menarik dan di pasarkan dengan strategi pemasaran yang apik menggunakan media sosial maka bisa meningkatkan penjualan serta pendapat mereka, bahkan produk meraka dapat dijual ke kota bahkan ke provins lainnya di Indonesia.

2. Kegiatan pendampingan yaitu satu persatu warga mencoba serta belajar secara langsung membuat akun media sosial Instagram dan cara menggunakan Instagram sebagai media pemasaran gula aren. Mereka lebih antusias karena dapat mencoba langsung membuat akun media sosial dan mengopersikannya untuk pemasaran gula aren. Ini adalah pengalaman baru dan mengasikkan bagi mereka.

Selanjutnya dilanjutkan dengan pembentukan komunitas pengusaha gula aren pada media sosial Instagram.

C. Tahap akhir yaitu evaluasi kegiatan secara menyeluruh. Setelah semua kegiatan selesai tim pengabdian melakukan evaluasi kegiatan agar mengetahui apa saja kekurangan dan kelebihan selama kegiatan workshop dan pendampingan berlangsung.

\section{SIMPULAN}

Kegiatan yang bersifat informatif melalui kegiatan workshop dan pendampingan dirasakan cukup efektif dan efisien. Besar harapan mereka bahwa kegiatan ini dapat dilakukan secara berkelanjutan dan berkesinambungan karena dampaknya dapat langsung di rasakan oleh warga Desa Ujung Tebu, Kecamatan Ciomas, Kabupaten Serang. Warga masyarakat mendapatkan manfaat yaitu tambahan wawasan ilmu pengetahuan mengenai pemasaran produk menggunakan

Dwi Nurina Pitasari,dkk., Pendampingan Pemasaran Gula Aren Menggunakan Media Sosial 
media sosial Instagram dan motivasi untuk terus banyak belajar agar kehidupan mereka dapat berubah menjadi lebih baik lagi dari kehidupan sekarang.

\section{REFERENSI}

Priansa, Donni Juni. 2017. Komunikasi pemasaran Terpadu. Bandung: Pustaka Setia.

Elvina, E. 2019. Pengaruh Penggunaan Media Sosial Terhadap Pengembangan Usaha Kecil Menengah (Ukm). Ecobisma (Jurnal Ekonomi, Bisnis Dan Manajemen), 2(1), 106118. https://doi.org/10.36987/ecobi.v2i1.722

Marthalena., Mardiana Siska, dan Berthanila Rethorika. Pemberdayaan Masyarakat Melalui Workshop dan Pendampingan Pengemasan Produk Emping Melinjo Dalam Meningkatkan Penjualan Di Desa Sindang Mandi Kecamatan Baros. Bantenese Jurnal Pengabdian Masyarakat. Vo. 1. No. 2 (2019) 99-108. (https://ejurnal.lppmunsera.org/index.php/PS2PM/article/view/1911)

Muningsih, E. 2014. Facebook Commerce, E-Commerce Pada Media Sosial Facebook Yang Modern Dan Populer. Bianglala Informatika, II(1), 11-18.

Suryani, I. .2015. Jurnal komunikasi, ISSN 1907-898X Volume 8, Nomor 2, April 2014, 8(April 2014), 123-138

Dwi Nurina Pitasari,dkk., Pendampingan Pemasaran Gula Aren Menggunakan Media Sosial Instagram di Desa Ujung Tebu Kabupaten Serang 